\section{Conducting Monetary Policy Without Government Debt: The Fed's Early Years}

\author{
David C. Wheelock
}

T he Federal Reserve System is the largest single owner of U.S. Treasury securities in the world, excluding federal government accounts and trust funds such as the Social Security and Medicare trust funds. As of January 2, 2002, the Federal Reserve System Open Market Account held \$554.8 billion of U.S. government securities, or about 16 percent of the stock of Treasury securities held outside of government accounts and trust funds. ${ }^{1}$ The Fed has acquired this portfolio through its monetary policy operations. Currently, the Fed implements its monetary policy by setting a target for the federal funds rate and using open market operations in U.S. government and agency securities to achieve that target. Purchases of securities supply reserves to the banking system, and thus tend to put downward pressure on the funds rate, whereas sales of securities remove reserves and put upward pressure on the funds rate. ${ }^{2}$

Federal Reserve holdings of government securities are the principal source of the nation's currency and depository institution reserve balances, and hence the U.S. monetary base. In principle, the Fed could add to the stock of bank reserves and currency by purchasing any asset, but U.S. Treasury securities offer at least two advantages over alternative assets for conducting monetary policy. First, because the Treasury market is extremely large and highly liquid, the Fed is able to conduct large transactions that give it substantial control over depository institution reserve balances and, hence, the federal funds rate, without having a disruptive impact on market prices. ${ }^{3}$ Second, by using open market transactions in Treasury debt to implement monetary policy, the Fed avoids directly affecting the allocation of private capital, which Federal Reserve Chairman

David C. Wheelock is an assistant vice president and economist at the Federal Reserve Bank of St. Louis. Heidi L. Beyer provided research assistance.

(c) 2002, The Federal Reserve Bank of St. Louis.
Alan Greenspan (2001) and other System officials have cited as an important consideration in the conduct of monetary policy. ${ }^{4}$

Because of the close relationship between Federal Reserve holdings of U.S. Treasury securities and the monetary base, as well as the advantages of using open market operations in Treasury securities to implement monetary policy, a substantial decline in the outstanding stock of Treasury debt would pose a major challenge to policymakers. Indeed, the stock of Treasury securities available to private holders, including the Fed, declined from 1997 to 2001, prompting Federal Reserve officials to consider how the Fed might conduct monetary policy in a world without a deep, liquid Treasury securities market.

The substantial size and liquidity of the U.S. Treasury securities market emerged during World War II. The stock of outstanding Treasury debt ballooned during the war and remained large during the ensuing 50 years because of nearly continuous annual federal budget deficits. Thus, for evidence on how monetary policy might be conducted without substantial reliance on Treasury debt, it is necessary to look either to the experiences of other countries or to the Fed's own history before World War II. Accordingly, this article describes the implementation of Federal Reserve monetary policy before World War II and highlights that era's experiences that offer lessons for the conduct of policy in a possible future world without Treasury debt.

The record of Federal Reserve policy before World War II is not good, and some scholars contend that the poor performance of monetary policy was caused by the System's desire also to affect the

\footnotetext{
1 Board of Governors of the Federal Reserve System Release H.4.1 (January 2, 2002)

2 Fed transactions take the form of outright purchases and sales, as well as repurchase and matched sale-purchase transactions, of Treasury and agency securities. The Fed enters the market nearly every business day to offset influences on reserve markets beyond the Fed's immediate control, such as changes in the amount of currency in circulation or in the size of U.S. Treasury balances at Federal Reserve Banks, that otherwise would cause the federal funds rate to deviate from the Fed's target. See Board of Governors of the Federal Reserve System (1994) for additional information about the implementation of monetary policy.

3 In 2001, the average daily volume of outright transactions in U.S. government securities, as reported by primary dealers, was $\$ 298$ billion. By contrast, in 2001, the Federal Reserve purchased an average of $\$ 5.7$ billion of Treasury securities per month. As noted, however, the Federal Reserve also engages in repurchase and matched purchasesale agreements. See Dupont and Sack (1999) for an overview of the U.S. Treasury securities market.

4 See also Broaddus and Goodfriend (2001).
} 


\section{Figure 1}

\section{U.S. Government Debt / GDP}

Annual data, 1917-2011*

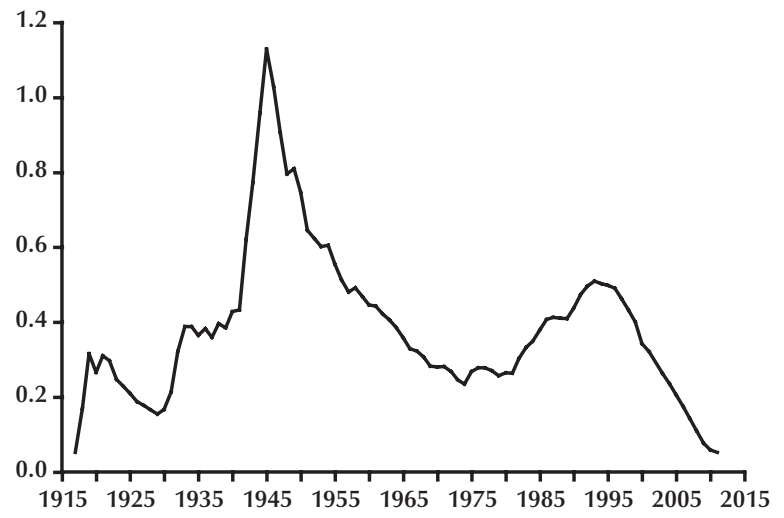

*CBO forecasts for 2001-11.

SOURCE: Board of Governors of the Federal Reserve System, Bureau of Economic Analysis, and Robert Gordon, Macroeconomics (2000)

private allocation of credit. This article describes the Fed's desire that the credit it supplied to markets not encourage financial speculation or other forms of "unproductive" activity and how that desire caused policymakers to tighten credit overzealously in response to a perceived misallocation in the late 1920s and remain too tight as the economy collapsed into the Great Depression. The views that led to this outcome do not influence Federal Reserve policy today. However, as Goodfriend (1994) and Schwartz (1992) contend, the Fed is at times pressured to conduct a targeted credit policy. Moreover, if the Fed were forced to conduct monetary policy using private debt instruments, which could occur if the stock of U.S. Treasury debt were to decline substantially, such pressures might increase. The Fed's prewar experience described here provides one example of how the conduct of an effective monetary policy can be compromised by pressures to affect the allocation of private-sector credit. 5

The next section discusses recent changes in the size of the U.S. Treasury debt and possible implications of a substantial decline in the outstanding stock of debt for the implementation of monetary policy. Following sections describe how the Fed's founders intended the System to conduct policy, the development of Federal Reserve monetary policy during the 1920s, and the conflicts created by the Fed's desire to prevent Federal Reserve credit from financing speculative activity. Those conflicts help explain the Fed's failure to respond aggressively to the Great Depression and illustrate how a policy focused on the usage of Federal Reserve credit can interfere with the implementation of an effective stabilization policy.

\section{THE RISE AND (POSSIBLE) FALL OF THE STOCK OF TREASURY DEBT}

As of December 31, 2001, the outstanding debt of the U.S. federal government totaled \$5943.4 billion, of which $\$ 2549.0$ billion was held by U.S. government agencies and trust funds such as the Social Security and Medicare trust funds. The remaining $\$ 3394.4$ billion of outstanding debt was held by the "public," consisting of private individuals, financial institutions and other firms, state and local governments, foreign concerns, and the Federal Reserve. ${ }^{6}$ The stock of government debt held by the public reached a year-end peak in 1997 at $\$ 3846.7$ billion. Since then, the surplus revenues of government trust funds invested in Treasury securities have exceeded the amount by which total Treasury debt has increased. ${ }^{7}$

Often, the stock of government debt is measured relative to national output and, presumably, the implications of a given amount of debt for monetary policy depend on the size of the economy. As Figure 1 illustrates, the ratio of U.S. government debt held by the public to gross domestic product (GDP) soared during World War II; it then declined steadily to the mid-1970s before rising again to a peak in 1993. Through September 2001 (the end of the fiscal year), the stock of Treasury debt then grew at a slower rate than did U.S. GDP. Projections by the Congressional Budget Office and other forecasters indicate that the debt-to-GDP ratio will continue to decline for at least the next decade. Past experience indicates that the size of the federal debt

\footnotetext{
5 Whereas the implementation of monetary policy using private credit instruments can lead to potential conflicts between the conduct of stabilization policy and the allocation of credit, analogous conflicts can arise if the central bank conducts open market transactions in any asset. For example, in the nineteenth and early twentieth centuries, U.S. silver mining interests often pressed the federal government to purchase and coin silver. Conceivably, such efforts to raise the relative price of silver could conflict with monetary policy objectives. See Friedman and Schwartz (1963, pp. 483-91) for a discussion of a silver purchase program implemented in the 1930s.

6 See < www.publicdebt.treas.gov/opd/opdpdodt.htm >

7 On September 30, 2001, the close of fiscal year 2001, the stock of debt held by the public totaled $\$ 3339.3$ billion.
} 
is difficult to forecast at horizons of more than a year or two (see Kliesen and Thornton, 2001). Nevertheless, if true, recent projections indicate that by mid-decade the debt-to-GDP ratio could fall to a level not observed since the 1920 s, and by about 2010 fall to a level not observed since before World War I. ${ }^{8}$

A substantial decline in the volume of outstanding Treasury securities would have repercussions for both the Fed and the financial system. Treasury securities, especially Treasury bills, serve as liquid, risk-free investments and collateral for banks and other financial market participants. For the Fed, either a substantial increase in discount window borrowing, which typically is secured by loans and other private claims, or greater use of securities other than those issued by the U.S. Treasury in the conduct of open market operations would expose the System to more credit risk than it faces today. Aside from possibly affecting monetary policy, such exposure could complicate other duties the Fed performs. For example, if the Fed were to become a major creditor of the banks that it supervises, then any aggressive actions it might take as a bank supervisor to deal with problem banks could increase the probability of losses by the Fed as a bank creditor.

The Fed has relied mainly on open market operations in Treasury debt to implement monetary policy since World War II. Recently, Federal Reserve Chairman Alan Greenspan (2001) summarized why Treasury securities are a convenient asset for the Fed to conduct its operations: "First, the liquidity of the market allows the Federal Reserve to make substantial changes in reserves in a short period of time, if necessary. Second, the size of the market has meant that the effects of the Federal Reserve's purchases on the prices of Treasury securities have been minimal. Third, Treasury securities are free of credit risk... [and] we believe that the effects of Federal Reserve operations on the allocation of private capital are likely to be minimized when Federal Reserve intermediation involves primarily the substitution in the public's portfolio of one type of instrument that is free of credit risk-currencyfor another-Treasury securities."

Greenspan went on to identify how the Fed might respond to a substantial decline in the stock of Treasury debt: "One possibility is to expand the use of the discount window by auctioning such credit to financially sound depository institutions... Another possibility is to add new assets to those the Fed is currently allowed by law to buy for its portfolio." Greenspan cited Ginnie Mae securities and certain types of municipal or foreign government obligations as examples of securities that the Fed might use for open market operations. Either increased reliance on the discount window (in which depository institutions borrow reserves mainly against collateral other than U.S. Treasury securities) or an expansion of the financial assets the Fed purchases in the open market would cause the implementation of monetary policy to resemble more closely the methods used by the Fed before World War II.

\section{WHAT THE FED'S FOUNDERS INTENDED}

In discussing the advantages of conducting open market operations in U.S. Treasury debt, Chairman Greenspan (2001) argued that "it is important that government holdings of assets not distort the private allocation of capital" and that "if the Treasury debt is paid down...then the Federal Reserve will have to find alternative assets that still provide substantial liquidity and minimize distortions to the private allocation of capital." The notion that actions to implement stabilization policy should not distort the private allocation of capital is not controversial today. When the Federal Reserve System was established in 1914, however, its founders very much did intend the System to favor certain uses of private sector capital over others. Moreover, the founders had no expectation that the Fed would conduct stabilization policy as we know it today. In short, the Fed's founders envisioned that the Fed would conduct credit policy, but not monetary policy, in that Federal Reserve operations were expected to influence the private allocation of credit but not regulate the growth rate of the monetary base or the level of interest rates to achieve macroeconomic stability. ${ }^{9}$

\section{The Discount Window}

The Fed's founders expected that Federal Reserve Banks, like the central banks of Europe, would serve mainly as lending institutions for their member commercial banks. Before the Fed's establishment, the U.S. commercial banking system suffered numer-

\footnotetext{
8 Projected annual ratios of debt to GDP for 2001-11 plotted in Figure 1 are from a Congressional Budget Office (2001) forecast made in August 2001, which was the latest available as of year-end 2001.

9 This distinction is discussed in Goodfriend (1994) and Broaddus and Goodfriend (2001).
} 
ous banking panics and, at times, high failure rates (see Dwyer and Gilbert, 1989). Proponents of the Federal Reserve System argued that the Fed would make the banking system more stable by providing commercial banks with a ready source of reserves to meet fluctuations in the demands for credit and currency. To perform that role, Federal Reserve Banks were given a lending facility - their discount windows - through which they would rediscount eligible financial assets for member commercial banks in exchange for currency or reserve deposit balances. ${ }^{10}$ Member banks were required to maintain minimum reserve balances with their Reserve Bank, and the Reserve System provided currency (Federal Reserve notes) and payments services for member institutions. ${ }^{11}$

The Federal Reserve Act provided that "any Reserve Bank may discount notes, drafts, and bills of exchange arising out of actual commercial transactions; that is, notes, drafts, and bills of exchange issued or drawn for agricultural, industrial, or commercial purposes." In addition, to be eligible for rediscount, agricultural paper could have a maturity of no more than six months, whereas nonagricultural paper had to mature in 90 days or less.

The limits that the Fed's founders placed on the type of securities eligible for rediscount with Reserve Banks reflected conventional banking principles of the time, the so-called Real Bills Doctrine. By limiting discount loans to short-term commercial and agricultural loans, the Fed's founders expected that the System would supply a sufficient volume of credit to accommodate growth and fluctuations in real economic activity without causing inflation or speculation. The Federal Reserve Act explicitly prohibited the rediscount of "notes, drafts, or bills covering merely investments or issued or drawn for the purpose of carrying or trading stocks, bonds, or other investment securities, except bonds and notes of the Government of the United States." By ruling such securities ineligible, the Fed's founders sought to prevent Federal Reserve credit from being used to finance transactions or investments that had no obvious, direct connection to the production, distribution, or sale of specific products or commodities. ${ }^{12}$

Apparently, the authors of the Federal Reserve Act believed it more important to specify precisely the type of securities that would be eligible for rediscount than to specify criteria for setting the discount rate. The Federal Reserve Act stated only that Reserve Bank discount rates should be determined "with a view of accommodating commerce and business."
Reserve Banks were required to maintain a gold reserve against their liabilities, however, which imposed implicit bounds on their lending rates.

\section{Open Market Operations in Bankers Acceptances}

The coalition of interests supporting the founding of the Federal Reserve System included both small community banks and large money center banks. ${ }^{13}$ The large money center banks were particularly interested in promoting the dollar as an international currency and thereby increasing the share of international transactions financed by U.S. banks (Broz, 1997). Accordingly, the Federal Reserve Act permitted U.S. commercial banks to issue bankers acceptances to finance foreign trade. The Act further sought to encourage the development of a U.S. acceptance market by permitting Federal Reserve Banks to acquire acceptances by rediscount or open market purchase. The Reserve Banks established interest rates at which they purchased all eligible acceptances offered to them, and such purchases were a major source of Federal Reserve credit during the System's first two decades.

\section{Open Market Operations in U.S. Government Securities}

In addition to open market purchases of bankers acceptances, the Federal Reserve Act authorized Reserve Banks "to buy and sell, at home or abroad, bonds and notes of the United States, and bills, notes, revenue bonds, and warrants...issued... by any State [sic], county, district, political subdivision, or municipality in the continental United States." This provision was intended to provide the Reserve Banks with a source of revenue in the event that income from

\footnotetext{
${ }^{10}$ At the time, most commercial and agricultural loans were made on a discount basis. Hence, when such loans were offered to Reserve Banks in exchange for currency or reserve balances, the Reserve Banks rediscounted the paper at the current discount rate.

11 The Fedwire system, which the Fed established in 1918 to effect interbank payments electronically, was among the innovations enhancing the liquidity of the payments system. See Gilbert (1998) for an analysis of how the founding of the Federal Reserve affected the efficiency of the U.S. payments system.

${ }^{12}$ Burgess (1936) and West (1977) discuss the objectives of the Fed's founders in detail.

${ }^{13}$ This is not to say that all banks favored the creation of the Fed. Numerous small, state-chartered banks elected not to join the System, and many opposed the Fed's check collection practices (see Gilbert, 1998). For further analysis of the Fed's "membership problem," see White (1983).
} 
rediscounts and the provision of services was insufficient to meet Bank expenses (Chandler, 1958, p. 76). The Fed's founders did not contemplate that open market operations would be used to influence the level of market interest rates or the growth rate of the money stock in an effort to stabilize the price level or economic activity. It was not long, however, before Federal Reserve policymakers discovered that open market operations could affect the level of interest rates and, potentially, influence economic activity.

\section{THE SOURCES OF FEDERAL RESERVE CREDIT}

Federal Reserve credit constitutes the Fed's contribution to the stock of bank reserves and currency in circulation, the sum of which is referred to as the monetary base or high-powered money. Other sources of the monetary base include Treasury currency outstanding (e.g., coins) and, historically, the monetary gold stock. The principal sources of Federal Reserve credit are discount window loans and Fed purchases of U.S. government securities. Before World War II, Fed purchases of bankers acceptances also contributed meaningfully to Fed credit. ${ }^{14}$

Figure 2 illustrates the relative volumes of discount window loans, Federal Reserve holdings of acceptances, and Fed holdings of U.S. government securities during 1914-41. Total Federal Reserve credit grew sharply during World War I, when the Fed committed itself to helping finance the war effort. The Federal Reserve Act was amended in 1916 to permit member banks to borrow directly from the Fed using U.S. government securities and other eligible assets as collateral. Discount loan volume soared when the Fed established preferential discount rates for advances secured by U.S. government securities that guaranteed banks a profit on their holdings of such securities. In June 1917, discount window loans outstanding (rediscounts and advances) totaled $\$ 197$ million, of which 13 percent were advances against member bank holdings of U.S. government securities. In June 1919, by contrast, discount loans totaled $\$ 1818$ million; of these, 87 percent represented rediscounts of, or advances against, U.S. government securities (Board of Governors, 1943, p. 340).

The Federal Reserve also purchased considerable U.S. government securities in the open market during the war. Fed holdings of Treasury securities increased from \$66 million in June 1917 to \$236

\section{Figure 2}

Principal Sources of Federal Reserve Credit Annual data, 1914-41

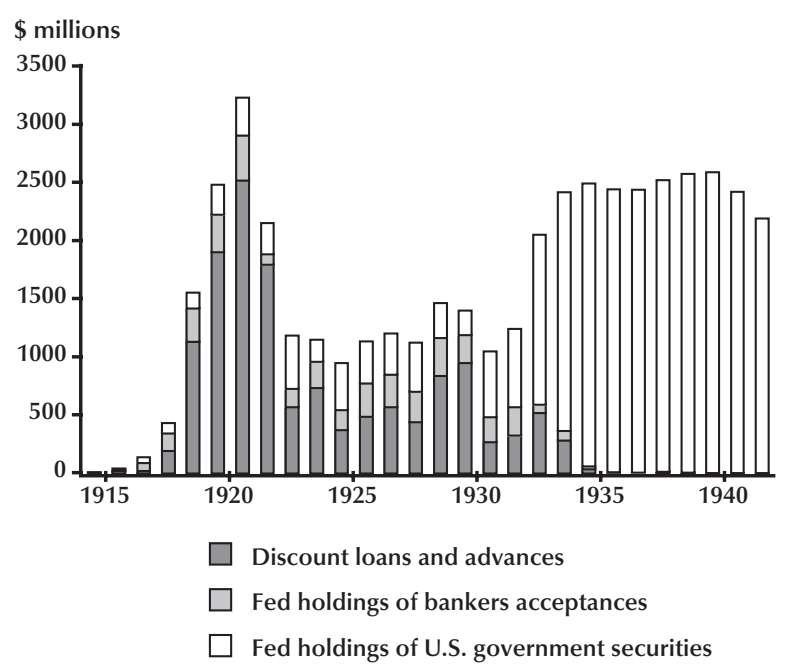

SOURCE: Board of Governors of the Federal Reserve System.

million in June 1919. The percentage of total Fed credit outstanding accounted for by Fed purchases of U.S. government securities remained at approximately 10 percent over the two years. Meanwhile, the Fed also acquired bankers acceptances in the open market. Throughout the war, more Federal Reserve credit was extended by the purchase of acceptances than by open market purchases of U.S. government securities.

The Fed retained preferential discount rates on loans secured by U.S. government securities after World War I. By late 1919, however, declining reserve ratios at several Reserve Banks prompted the Banks to increase their discount rates and to discontinue preferential rates on loans secured by U.S. government securities. ${ }^{15}$ Discount window loan volume dropped sharply in 1921-22. From a peak of $\$ 2808$ million in October 1920, discount loans outstanding fell to less than $\$ 400$ million in August 1922 (Board of Governors, 1943, p. 374).

The Reserve Banks sought to offset the loss of revenue associated with the decline in discount loans by purchasing government securities in the

\footnotetext{
${ }^{14}$ Other sources of Fed credit include check float and Federal Reserve purchases of foreign currency.

${ }^{15}$ Reserve Banks were required by law to maintain reserves of gold and eligible securities against their outstanding liabilities.
} 
open market (Chandler, 1958, p. 209). Open market operations in government securities remained an important source of Federal Reserve credit throughout the 1920s and even more so during the early 1930s, when discount window loans and Federal Reserve purchases of bankers acceptances dwindled. By 1932, open market purchases of U.S. government securities had become the dominant source of Federal Reserve credit, and for the remainder of the decade the Fed made almost no discount loans and purchased almost no bankers acceptances.

\section{MONETARY VERSUS CREDIT POLICY}

The changes in the composition of Federal Reserve credit during the 1920s reflect well the evolution from the self-regulating credit policy envisioned by the Fed's founders toward a modern monetary policy. By the mid-1920s, the Fed had begun to use open market operations in U.S. government securities to influence money market conditions, with the twin goals of promoting domestic economic stability and the international gold standard. Credit policy came back to the fore in 1928-29, however, when the Fed sought to check stock market speculation without unduly restricting the flow of credit to "legitimate" borrowers. The consequent stance of monetary policy proved extremely restrictive, the stock market crashed, and the U.S. economy collapsed. ${ }^{16}$ The Fed did not ease monetary policy aggressively in response to the collapse, however, in part because some Fed officials feared that loose monetary policy would reignite financial speculation. This section discusses the origins of Federal Reserve monetary policy during the 1920s and the conflict between monetary and credit policy that emerged during the late 1920s. The following section explores how this conflict influenced the setting of monetary policy during the Great Depression.

\section{The Birth of Monetary Policy}

Although the provisions of the Federal Reserve Act permitting the Reserve Banks to acquire government securities were little more than an afterthought, Reserve Bank officials, especially at the Federal Reserve Bank of New York, observed that their purchases affected market interest rates and credit conditions. After World War I, the Reserve Banks formed a committee of Reserve Bank governors, headed by Federal Reserve Bank of New York Governor Benjamin Strong, to establish policies for the conduct of open market operations and to coordinate open market purchases for all Reserve Banks. ${ }^{17}$ Strong, according to Chandler (1958), was among the first Reserve System officials to comprehend the impact of open market operations on money market and credit conditions, as well as to favor the use of open market operations to achieve general macroeconomic goals.

Under Strong's leadership, the Fed began to use open market operations in U.S. government securities during the 1920s to implement an active monetary policy. This policy clashed with the credit policy objectives of members of the Federal Reserve Board and some Reserve Banks. This conflict came to a head over how to control stock market speculation in 1928-29 and how to respond to the economic depression that followed the stock market crash in 1929.

Strong directed two major monetary policy operations during the 1920s, involving substantial open market purchases in 1924 and 1927. The motivation for these operations has been debated. Chandler (1958), Friedman and Schwartz (1963), Meltzer (1997), and Wicker (1966) all argue that Strong was motivated by a desire to ease money market conditions, but they disagree about Strong's ultimate objective. Friedman and Schwartz (1963) contend that in both years Strong was motivated primarily by a desire to promote domestic recovery from a recession. Wicker (1966), however, argues that Strong's primary motivation was to redirect the international flow of gold away from the United States toward the United Kingdom, in an effort to help Britain first restore, then preserve, gold convertibility of the pound. Chandler (1958) and Meltzer (1997) contend that both objectives were important, and Wheelock (1991) reports econometric evidence consistent with their conclusion.

Whatever Strong's motivation, his use of open market operations caused considerable controversy within the Federal Reserve System. Strong's initiative irritated members of the Federal Reserve Board, who believed that the committee of governors had overstepped its authority. Several members of the Board also opposed open market purchases, espe-

\footnotetext{
${ }^{16}$ Schwartz (1981) and Hamilton (1987) argue that tight monetary policy in 1928-29 was an important cause of the Great Depression.

${ }^{17}$ From 1914 to 1935 , the chief executive officer of each Federal Reserve Bank held the title "governor," as did the chair of the Federal Reserve Board. The Banking Act of 1935 changed the title of Reserve Bank chief executives to "president" and assigned the title "governor" to each member of the Federal Reserve Board, which was renamed the Board of Governors of the Federal Reserve System.
} 
cially in 1927, on economic grounds. Most members of the Board, and officials of some Reserve Banks, believed that Federal Reserve credit should be extended only at the initiative of member commercial banks through the rediscounting of commercial and agricultural loans. Otherwise, those officials argued, the Fed risked contributing to speculative activities that could prove harmful to the economy.

Strong, on the other hand, contended that the Fed could help lift the economy during a period of weakness by using open market purchases to ease monetary conditions. At a meeting of Reserve Bank governors in 1926, Strong argued: "Should we go into a business recession while the member banks were continuing to borrow [from Reserve Bank discount windows]... we should consider taking steps to relieve some of the pressure which this borrowing induces by purchasing Government securities and thus enabling member banks to reduce their indebtedness" (quoted in Chandler, 1958, pp. 239-40). In Strong's view, by enabling banks to repay their discount window borrowings, open market purchases would ease money market conditions and promote economic recovery.

\section{The Stock Market and the Return of Credit Policy}

Although the disagreements about open market purchases in 1924 and 1927 were sharp, the most heated debates within the System during the 1920s focused on how the Fed should respond, if at all, to the rising stock market. The rapid increase in stock prices and growth of loans from banks and brokers to finance stock purchases in 1928 and 1929 concerned System officials who sought to ensure that reserves supplied by the Fed were not being used to finance speculation. Most members of the Federal Reserve Board favored a "direct action" policy in which member banks with outstanding loans to finance stock purchases would be prohibited from borrowing at the discount window. Board members thought that by enforcing this restriction, discount rates would not have to rise and thereby penalize borrowers with "legitimate" credit demands.

Officials of Federal Reserve Banks, however, generally believed it neither practical nor desirable for the Fed to affect the private allocation of credit. In a 1925 memorandum, Benjamin Strong asked rhetorically how the Fed should respond to calls for action against real estate and stock market speculation or, for example, to "too much enthusiasm in automobile production":
Where does our responsibility lie? Must we accept parenthood for every economic development in the country? That is a hard thing for us to do. We would have a large family of children. Every time any one of them misbehaved, we might have to spank them all. There is no selective process in credit operations. If we undertake "direct action" in one case, we would be saddled with the responsibility for direct action in all cases. Have we infallible good judgment as well as sufficient knowledge to play the role of parent?... Of one thing I am sure... and that is that we have no direct responsibility to deal with isolated situations, and must rely for the development of our policy upon estimates of the whole situation. (quoted in Chandler, 1958, p. 428)

In Strong's view, the Fed should be concerned with the stock market, or any other particular market, only to the extent that it bears on the behavior of the economy as a whole.

To the extent that a rising stock market meant that monetary policy should become tighter, Strong favored raising the discount rate and conducting open market sales, rather than placing special restrictions on banks that made stock market loans. Such restrictions, he argued, would not limit the flow of credit to the stock market: "the money will go into the stock exchange anyway" (quoted in Chandler, 1958, p. 430). Even if the Fed lent only to banks that made no stock market loans, Strong claimed, reserves supplied through the discount window (or via open market purchases) could still end up enabling banks in the aggregate to increase stock market loans: "If we create an addition to the volume of credit by our open-market operations or by our discounts, the banks which get it [i.e., the credit] pass it along through all the channels through which credit circulates in our banking system - and we cannot control what happens to it. Some of it will go in one direction and some of it will go in another, and the nature and the use of our funds is perfectly impossible to control" (quoted in Chandler, 1958, pp. 431-32).

\section{Direct Action}

At its meeting on January 11, 1928, the Federal Reserve's open market committee decided to implement a more restrictive monetary policy, defined as "somewhat firmer money conditions," so as to 
"check unduly rapid further increases in the volume of credit" (quoted in Chandler, 1971, p. 38). The Reserve Banks also began to increase their discount rates and, for the most part, these initial restrictive actions were supported by the Federal Reserve Board. One Board member, however, dissented from all moves to tighten policy. In explaining his vote against a discount rate increase in 1928, Edward Cunningham stated that "I feel that increases in the discount rate for the purpose of restricting stock market activities should only be resorted to when other means within the power of the Board have failed to accomplish the objective. I am not in favor of penalizing agriculture and business because of the indirect use of credit for investments in brokers loans" (quoted in Chandler, 1971, p. 43).

Despite further discount rate increases and open market sales in 1928, Fed officials were frustrated by their apparent inability to control the flow of credit to the stock market. Chandler (1971, pp. 5253) summarizes the quandary the Fed found itself in at the beginning of 1929 :

By late January 1929 the Federal Reserve's policy of restriction had been in effect about a year. Monetary and credit conditions had changed markedly during the period. Member bank borrowings at the Federal Reserve had nearly doubled, rising to nearly $\$ 900$ million, equal to 37 percent of total bank reserves...The total volume of bank credit was barely above its level of a year earlier. Interest rates had risen sharply...Call-loan rates averaged above 7 percent in December 1928 and frequently reached considerably higher levels. However, the Federal Reserve had not achieved its objective of curbing stock speculation. Share prices rose 38 percent in the year... Brokers' loans reached the unprecedented level of $\$ 6.4$ billion; this reflected an increase of 45 percent for the year...Domestic business activity was still at high and rising levels, but even here there were warning signs in the form of decreasing availability of mortgage money, a downturn in construction, and increasing difficulties in floating long-term bond issues.

In these circumstances, disagreements within the System over how to respond to the stock market became more heated.

Federal Reserve Board officials believed that the Reserve Banks had not properly administered their discount windows and were permitting member banks to borrow reserves to support "speculative" lending, meaning primarily loans to stock brokers and dealers and to customers for the purpose of purchasing securities. Although Reserve Banks rediscounted only loans and securities that were eligible as defined by the Federal Reserve Act, Board officials argued that commercial banks should be forced to liquidate their speculative loans before being permitted to rediscount (or borrow against) eligible paper. On February 2, 1929, the Federal Reserve Board sent a letter to each of the 12 Reserve Banks in which the Board stated that

The Federal Reserve Act does not...contemplate the use of the resources of the Federal reserve banks for the creation or extension of speculative credit. A member bank is not within its reasonable claims for rediscount facilities at its Federal reserve bank when it borrows either for the purpose of making speculative loans or for the purpose of maintaining speculative loans.

The letter went on to request that each Reserve Bank report to the Board as to "a) how they keep themselves fully informed of the use made of borrowings by their member banks, $b$ ) what methods they employ to protect their institution against the improper use of its credit facilities by member banks, and c) how effective these methods have been" (quoted in Chandler, 1971, pp. 56-57).

Although the Board's instructions to the Reserve Banks were vague - for example, the terms "speculative credit" and "speculative loans" were not defined-the Reserve Banks made some effort to comply with the Board's request that they administer their discount windows more tightly. At the same time, the Reserve Banks pressed for increases in their discount rates, but were denied by the Federal Reserve Board. Consequently, Reserve Bank officials grew increasingly frustrated with the Board's "direct action" policy of tightly restricting access to the discount window. As George Norris, Governor of the Federal Reserve Bank of Philadelphia, complained to one Board member:

This whole process of "direct action" is wearing, friction-producing, and futile. We are following it honestly and energetically, but it is manifest, beyond...doubt, that it will never get us anywhere. It is like punching at a mass of dough. You make a dent where 


\section{Figure 3}

Principal Sources of Federal Reserve Credit Monthly data, January 1928-February 1933

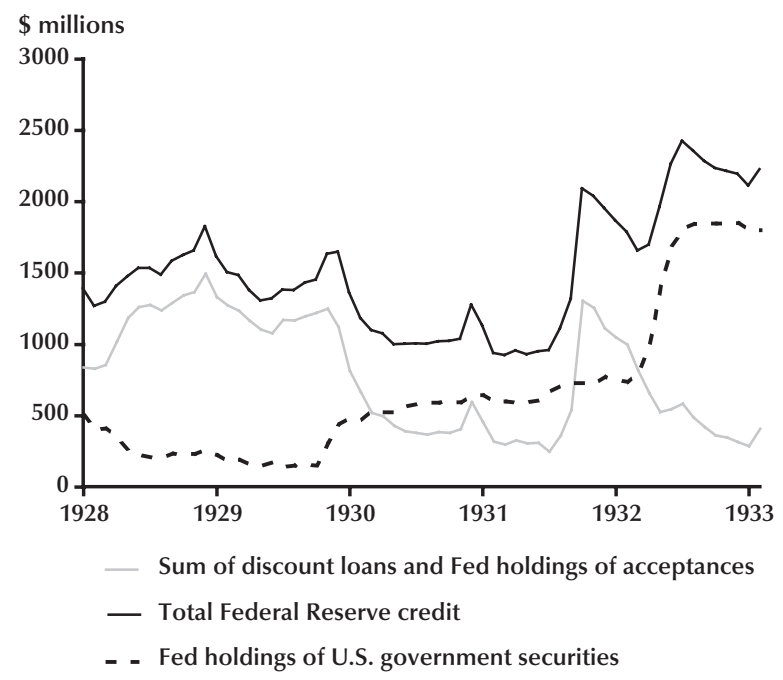

SOURCE: Board of Governors of the Federal Reserve System.

you hit, but the mass swells up at another point. As long as we maintain a discount rate which is absurdly low, and out of proportion to all other rates, the present conditions will continue. Our 5 per cent rate is equivalent to hanging a sign out over the door "Come in," and then we have to stand in the doorway and shout "Keep out." It puts us in an absurd and impossible position. (Quoted in Chandler, 1971, p. 66)

\section{THE CRASH AND GREAT DEPRESSION}

The Federal Reserve Board eased its policy of "direct action" in June 1929, when economic activity had begun to slow and Fed officials were concerned that credit had become too tight. In August, however, the discount rate of the Federal Reserve Bank of New York was increased in an effort to discourage borrowing, and market interest rates remained high until the stock market crashed in October. Rates then fell sharply. The crash prompted the Federal Reserve Bank of New York to make large open market purchases while also lending heavily through its discount window. The Federal Reserve, however, did not respond aggressively to the sharp decline in economic activity that followed the stock market crash or to the banking panics that occurred over the

\section{Figure 4}

M1 Money Stock and Total Bank Reserves Monthly data, January 1928-February 1933

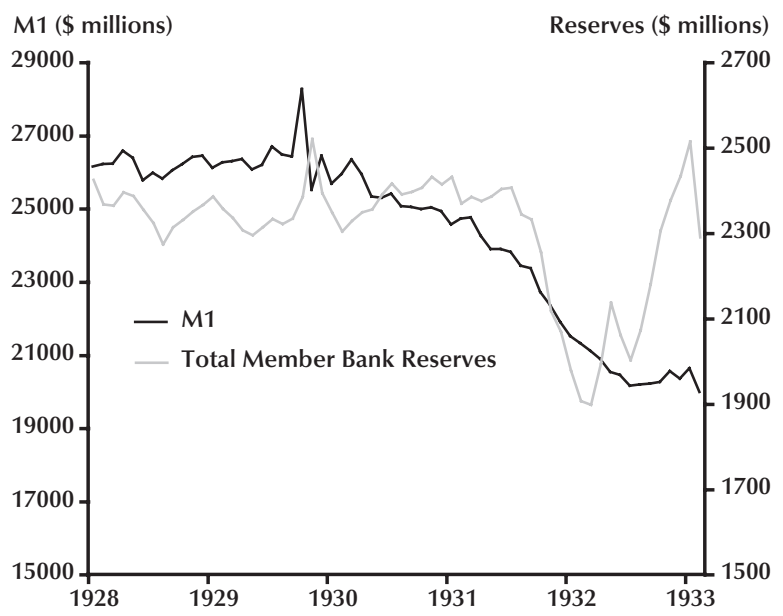

SOURCE: Board of Governors of the Federal Reserve System and Friedman and Schwartz (1963) for M1.

next three years. ${ }^{18}$ One reason for the Fed's inaction is that Federal Reserve officials remained mired in debate over whether the System should attempt to channel credit to "appropriate" uses or pursue an active stabilization policy. This section reviews that debate, focusing on the arguments of Fed officials who opposed the use of expansionary monetary policy to revive the economy.

\section{The Fed's Response}

The Federal Reserve Bank of New York purchased some $\$ 160$ million of government securities for its own account immediately following the stock market crash, and the System purchased another \$150 million of securities before the end of 1929. During 1930 and most of 1931, however, Fed pur chases of government securities were insufficient to offset net declines in discount window loans and Fed purchases of bankers acceptances. Hence, total Federal Reserve credit outstanding fell (see Figure 3). As Friedman and Schwartz (1963) show, the money stock began to fall in this phase of the Depression (see Figure 4).

Monetary contraction accelerated in the fourth quarter of 1931, when speculation that the United

\footnotetext{
18 Macroeconomic conditions during the Depression are summarized
} in Wheelock (1992) 
States would abandon the gold standard triggered bank runs and a gold outflow. Banks borrowed heavily from the discount window to replace lost reserves and Federal Reserve credit increased sharply. The Fed did not make substantial open market purchases of government securities, however, claiming that it lacked sufficient gold reserves. ${ }^{19}$

Easier monetary policy did come in 1932 when, under pressure from Congress, the Fed purchased some $\$ 1$ billion of U.S. government securities between March and August. ${ }^{20}$ The total increase in Federal Reserve credit was less than $\$ 1$ billion because of declines in discount window loans and Fed holdings of bankers acceptances, but member bank reserves increased and the money stock stopped falling. The banking crisis resumed in early 1933, however, triggering a series of state bank suspensions and prompting President Franklin Roosevelt to declare a national bank holiday and suspend the gold standard when he took office in March. The Federal Reserve, meanwhile, stayed in the shadows as the new president took charge of macroeconomic policy.

\section{How Should the Fed Respond to a Decline in Economic Activity?}

Why the Federal Reserve failed to respond more aggressively to the Great Depression has been the subject of considerable research. ${ }^{21}$ Certainly, there were officials in the System who advocated a more vigorous response to the Depression. Officials of the Federal Reserve Bank of New York, for example, argued that recovery required low interest rates, a strong bond market, and a sufficient supply of reserves to free member banks from having to obtain discount window loans. ${ }^{22}$ In July 1930, New York Fed Governor George Harrison wrote to his counterparts at other Reserve Banks urging that the Fed "do everything possible and within its power to facilitate a recovery of business." He went on to advocate open market purchases: "In previous business depressions, recovery has never taken place until there has been a strong bond market," and, moreover, "we cannot foresee any appreciable harm" from making open market purchases (quoted in Friedman and Schwartz, 1963, p. 370).

Outside of New York, however, many Fed officials were convinced that Federal Reserve credit should contract with declines in economic activity and loan demand. Those officials claimed that in the absence of demand for loans by business and agri- cultural borrowers, reserves created by an expansion of Federal Reserve credit would be used to finance speculation. Many argued that open market purchases during recessions in 1924 and 1927 had been a mistake and had contributed to the financial speculation that they saw as responsible for the subsequent economic depression. For example, Adolph Miller, a member of the Federal Reserve Board who had voted against open market purchases in 1927, testified in 1931 that the operation "was the greatest and boldest operation ever undertaken by the Federal Reserve System, and, in my judgment, resulted in one of the most costly errors committed by it or any banking system in the last 75 years... That was a time of business recession. Business could not use and was not asking for increased money at that time" (U.S. Senate, 1931, p. 134).

Miller's view was not unique among System officials. In response to a written question from the Senate Banking Committee in 1931 about open market purchases in 1924 and 1927, officials of the Federal Reserve Bank of Richmond wrote that "we think United States securities should not have been purchased in these periods, and the aim should have been to decrease rather than augment the total supply of Federal Reserve credit" (U.S. Senate, 1931, p. 100). Officials of the Federal Reserve Bank of Philadelphia responded similarly, arguing that Federal Reserve credit should never be extended except at the initiative of member banks. Other Reserve Banks replied that the open market purchases of 1924 and 1927 had been justified, but were too large.

\footnotetext{
19 Burgess (1936, pp. 285-86) argues that the Fed was constrained by a lack of gold reserves, but Friedman and Schwartz (1963, pp. 399-406) dismiss the Fed's excuse. See also Chandler (1971, pp. 182-91).

20 The Glass-Steagall Act of 1932 permitted the Fed to back Federal Reserve notes with U.S. government securities, which greatly eased the Fed's gold reserve requirement.

${ }^{21}$ See Friedman and Schwartz (1963), Wicker (1966), Brunner and Meltzer (1968), Wheelock (1991, 1992), and Meltzer (1994).

22 During the Depression, Fed officials interpreted historically low levels of borrowed reserves and interest rates as indicating that monetary conditions were exceptionally easy. No one in the System, and almost no one outside the Fed, recognized that a falling price level and widespread banking panics, let alone a decline in the money stock, meant that monetary policy was in fact exceptionally tight. Friedman and Schwartz (1963) argue that the Fed would have responded much more aggressively to the Depression had Benjamin Strong not died in 1928 During the 1920s, however, Strong advocated basing the volume of open market operations on the levels of borrowed reserves and market interest rates; the Fed's anemic response to the Depression does not seem inconsistent with that framework (see Wheelock, 1990, 1991, 1992).
} 
Those officials who were critical of open market purchases during the 1920 s tended to argue that Federal Reserve credit should be extended only at the initiative of member banks, through the discount window or by sales of bankers acceptances to the Fed. Open market purchases of government securities, by contrast, constituted "artificial" easing, which Federal Reserve Bank of St. Louis Governor William McChesney Martin Sr. argued was "unwise" and possibly "hazardous" (quoted in Chandler, 1971, p. 142). The Federal Advisory Council argued similarly in 1930 that "the present situation will be best served if the natural flow of credit is unhampered by open-market operations" (quoted in Friedman and Schwartz, 1963, p. 373). Such operations, claimed Chairman Richard Austin of the Federal Reserve Bank of Philadelphia, "lays us open to the apparent undesirable charge that the action is not justified by the demand for credit but for some other purpose, it may be for boosting business, making a market for securities, or some other equally criticizable cause that certainly will come back to plague us" (quoted in Chandler, 1971, p. 136).

Several Fed officials argued that monetary policy could do little to bring about recovery from the Depression. Officials of the Federal Reserve Bank of Philadelphia, for example, concluded that "the correction must come about through reduced production, reduced inventories, the gradual reduction of consumer credit, the liquidation of security loans, and the accumulation of savings through the exercise of thrift" (quoted in Chandler, 1971, p. 137). And, in response to a proposal for open market purchases, Governor James McDougal of the Federal Reserve Bank of Chicago replied that the market already had an "abundance" of funds. Further, he argued that the Fed should "maintain a position of strength, in readiness to meet future demands... rather than to put reserve funds into the market when not needed" (quoted in Friedman and Schwartz, 1963, p. 371).

In the view of McDougal and several other Fed officials, open market purchases would have little positive impact on economic activity and could in fact interfere with economic recovery by delaying the liquidation of loans and speculative investments that, in their view, was necessary for recovery to begin. Moreover, in the absence of an obvious demand for Federal Reserve credit, as evidenced by discount window borrowing or sales of bankers acceptances to Reserve Banks, McDougal and others believed that reserves created by open market purchases could result in a dangerous misallocation

\section{Figure 5}

Government Security Holdings as a Percent of Total Adjusted Federal Reserve Credit* Annual data, 1915-2001

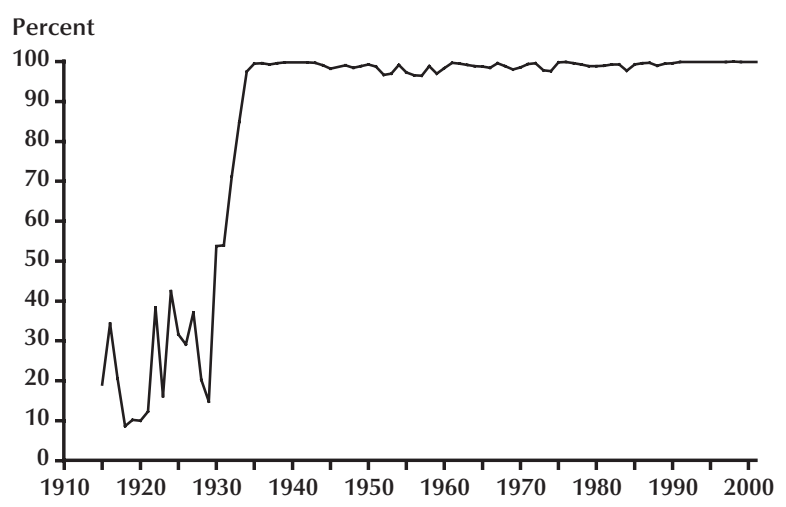

*Total adjusted Federal Reserve credit = Sum of discount loans and advances to depository institutions and Federal Reserve holdings of U.S. government and other securities.

SOURCE: Board of Governors of the Federal Reserve System.

of credit. They were not able to prevent open market purchases altogether, but their resistance undoubtedly slowed the Fed's response to the Great Depression.

\section{LESSONS}

Ironically, the Fed's unwillingness to purchase a large volume of government securities early in the Depression ultimately may have contributed to such purchases becoming the dominant source of Federal Reserve credit. As the Depression continued and banking panics worsened, commercial banks became increasingly unable and unwilling to come to the discount window. Some banks lacked eligible collateral for discount window loans, while others feared that borrowing would trigger deposit withdrawals by giving the appearance of weakness. ${ }^{23}$ By 1932, discount window borrowing and Federal Reserve purchases of bankers acceptances had fallen to minimal levels, where they stayed throughout the remainder of the decade. As Figure 5 illustrates, Fed holdings of U.S. government securities had become by far the most important source of Federal Reserve credit. Since 1934, the size of the Fed's

\footnotetext{
${ }^{23}$ Chandler (1971, pp. 225-33) concludes that borrowing was reduced to some extent by a lack of eligible collateral and a heightened reluctance to borrow. Wheelock (1990) finds that discount window borrowing declined more during 1930-33 than could be explained simply by the decline in economic activity.
} 
portfolio of U.S. government securities has always comprised over 90 percent of total adjusted Federal Reserve credit outstanding (the sum of discount loans and Fed holdings of U.S. government and other securities).

Monetary policy lay dormant from the mid-1930s to 1951. Neither the size of the Fed's government security portfolio nor total Fed credit outstanding changed substantially between 1934 and 1941.24 During World War II and for several years subsequently, the Fed's open market operations were directed entirely at maintaining low and stable yields on U.S. Treasury securities, while discount window borrowing and Fed acceptance purchases remained minimal. An agreement between the Federal Reserve and the Treasury in March 1951 (the "Accord") freed the Fed from rigid support of U.S. Treasury security prices, enabling the System to pursue broader policy objectives (Hetzel and Leach, 2001a). Under William McChesney Martin Jr., who became Chairman of the Federal Reserve's Board of Governors following the Accord, the Fed initiated an active monetary policy designed to limit inflation and the amplitude of business cycles (Hetzel and Leach, 2001b). To achieve those goals, the Fed has relied primarily on open market operations in U.S. government securities to manipulate the volume of bank reserves and influence market interest rates. Although at times the quantity of discount window borrowing has been an operational target for open market policy, discount loans have been a far less important source of Federal Reserve credit since 1951 than they were before 1934, as have Fed purchases of bankers acceptances (see Figure 5). ${ }^{25}$

Whereas the Great Depression was a defining moment in the conduct of U.S. monetary policy (Calomiris and Wheelock, 1998), it perhaps had even more impact on the regulation of the financial system and the government's role in credit allocation. A host of federal loan corporations and other agencies to allocate credit, such as the Reconstruction Finance Corporation, were founded or expanded. The widely held view that stock market speculation and commercial bank involvement in the underwriting, sale, and financing of security purchases had caused the Depression led to fundamental reforms of securities markets and the banking system, including the Glass-Steagall Act of 1933, which prohibited the commingling of commercial and investment banking.

The Federal Reserve also was given expanded powers to influence the allocation of credit. The
Federal Reserve Act was amended in 1933 to authorize the Fed to set minimum margin requirements for stock market loans, while giving the Federal Reserve Board clear authority to deny discount window loans to banks that made speculative loans. At the same time, the definition of acceptable collateral for discount window loans was broadened and the Fed was authorized under certain circumstances to make loans to nonmember banks, groups of banks, and even to individuals, partnerships, and corporations (Hackley, 1973).

Since the Accord, the Federal Reserve has effectively insulated its monetary policy from credit allocation. Discount window lending has been a small fraction of total Federal Reserve credit, and the Fed largely discontinued the purchase of bankers acceptances in the 1950s, though authorization to purchase acceptances was not eliminated until 1998. Moreover, discount window loans and other Federal Reserve transactions, such as foreign exchange market intervention and warehousing, are prevented from affecting the monetary base by means of offsetting open market operations.

Goodfriend (1994) contends that pressure to allocate credit could still be detrimental to monetary policy. At times, Congress and the Administration have called upon the Fed to lend to distressed firms and governments, such as Penn Central Corporation in 1970 and New York City in 1975 (see Schwartz, 1992). Although the Fed has usually resisted such calls, Goodfriend (1994) argues that pressure put on the Fed to conduct targeted credit policy threatens the Fed's independence, which he views as crucial to the conduct of effective monetary policy. Arguably, if the Fed were to rely more heavily on discount window lending or to conduct open market operations in assets other than U.S. Treasury securities, the System could face intensified pressure to alter the composition of its asset portfolio. The experience of the Fed during the Great Depression suggests that a desire to affect the allocation of credit, even one

\footnotetext{
24 The Fed's few open market purchases maintained a constant-size portfolio as holdings matured. Gold inflows from abroad poured reserves into the U.S. banking system, however, and banks amassed high levels of reserves in excess of legal requirements. This "golden avalanche" produced rapid growth of the money stock (Friedman and Schwartz, 1963). The Fed did raise bank reserve requirements in 1936 and 1937, fearing the inflationary potential of excess reserves, and lowered them under pressure from the Administration in 1938 when the economy slipped into recession. See Calomiris and Wheelock (1998) for discussion

${ }^{25}$ See Meulendyke (1989) for an overview of monetary policy since the Accord.
} 
that originates from within the Federal Reserve System, could undermine its monetary policy.

When direct lending to commercial banks was an important source of Federal Reserve credit, Federal Reserve officials became concerned that banks were not employing the reserves they acquired through the discount window appropriately. Elaborate collateral requirements were imposed by the Federal Reserve Act, and at various times the Fed reiterated that borrowing is a privilege, not a right. Still, Fed officials became dissatisfied with the use of credit and sought to impose tight controls to limit borrowing. The result was an exceptionally tight monetary policy that carried over into the Great Depression, when many Fed officials feared that aggressive monetary easing would only reignite financial speculation.

The Federal Reserve is unlikely to repeat the egregious error of contracting Federal Reserve credit and the monetary base during a serious economic downturn. However, if direct lending to financial institutions or open market operations in assets other than U.S. Treasury securities become important in the implementation of monetary policy, the Fed's early history warns that new pressures to conduct a credit policy could arise that might hamper the conduct of monetary policy.

\section{REFERENCES}

Board of Governors of the Federal Reserve System. Banking and Monetary Statistics, 1914-1941. Washington, DC, 1943.

The Federal Reserve System: Purposes and Functions. Washington, DC, 1994.

Broaddus, J. Alfred Jr. and Goodfriend, Marvin. "What Assets Should the Federal Reserve Buy?" Federal Reserve Bank of Richmond 2000 Annual Report, 2001.

Broz, J. Lawrence. The International Origins of the Federal Reserve System. Ithaca, NY: Cornell University Press, 1997.

Brunner, Karl and Meltzer, Allan H. "What Did We Learn from the Monetary Experience of the United States in the Great Depression?" Canadian Journal of Economics, May 1968, pp. 334-48.

Burgess, W. Randolph. The Reserve Banks and the Money Market. New York: Harper and Brothers, 1936.

Calomiris, Charles W. and Wheelock, David C. "Was the Great Depression a Watershed for American Monetary
Policy?" in Michael D. Bordo, Claudia Goldin, and Eugene N. White, eds., The Defining Moment: The Great Depression and the American Economy in the Twentieth Century. Chicago: University of Chicago Press, 1998, pp. 23-66.

Chandler, Lester V. Benjamin Strong: Central Banker. Washington, DC: The Brookings Institution, 1958. American Monetary Policy, 1928-1941. New York: Harper and Row, 1971.

Congressional Budget Office. The Budget and Economic Outlook. August 2001. < www.cbo.gov > (as posted July 11, 2001).

Dupont, Dominique and Sack, Brian. "The Treasury Securities Market: Overview and Recent Developments.” Board of Governors of the Federal Reserve System Federal Reserve Bulletin, December 1999, pp. 785-806.

Dwyer, Gerald P. Jr. and Gilbert, R. Alton. "Bank Runs and Private Remedies." Federal Reserve Bank of St. Louis Review, May/June 1989, 71(3), pp. 43-61.

Friedman, Milton and Schwartz, Anna J. A Monetary History of the United States, 1867-1960. Princeton, NJ: Princeton University Press, 1963.

Gilbert, R. Alton. "Did the Fed's Founding Improve the Efficiency of the U.S. Payments System?" Federal Reserve Bank of St. Louis Review, May/June 1998, 80(3), pp. 121-42.

Goodfriend, Marvin. "Why We Need an 'Accord' for Federal Reserve Credit Policy: A Note.” Journal of Money, Credit, and Banking, August 1994, 26(3), pp. 572-80.

Greenspan, Alan. “The Paydown of Federal Debt.” Remarks before the Bond Market Association, White Sulphur Springs, West Virginia, 27 April 2001.

Hackley, Howard H. Lending Functions of the Federal Reserve Banks: A History. Washington, DC: Board of Governors of the Federal Reserve System, 1973.

Hetzel, Robert L. and Leach, Ralph F. "The Treasury-Fed Accord: A New Narrative Account." Federal Reserve Bank of Richmond Economic Quarterly, Winter 2001a, 87, pp. 33-55.

and "After the Accord:

Reminiscences on the Birth of the Modern Fed." Federal 
Reserve Bank of Richmond Economic Quarterly, Winter 2001b, 87, pp. 57-64.

Hamilton, James D. "Monetary Factors in the Great Depression.” Journal of Monetary Economics, March 1987, 19(2), pp. 145-69.

Kliesen, Kevin L. and Thornton, Daniel L. "The Expected Federal Budget Surplus: How Much Confidence Should the Public and Policymakers Place in the Projections?" Federal Reserve Bank of St. Louis Review, March/April 2001, 83(2), pp. 11-24.

Meltzer, Allan H. "Why Did Monetary Policy Fail in the 1930s?” Working paper, 1994.

"New Procedures, New Problems." Working paper, 1997

Meulendyke, Ann-Marie. U.S. Monetary Policy and Financial Markets. New York: Federal Reserve Bank of New York, 1989.

Schwartz, Anna J. "Understanding 1929-1933," in Karl Brunner, ed., The Great Depression Revisited. Boston: Martinus Nijhoff, 1981, pp. 5-48.

"The Misuse of the Fed's Discount Window." Federal Reserve Bank of St. Louis Review, Septemberl
October 1992, 74(5), pp. 58-69.

U.S. Senate, Committee on Banking and Currency, 71st Congress, 3rd Session. Operation of the National and Federal Reserve Banking Systems. Washington, DC: Government Printing Office, 1931.

West, Robert C. Banking Reform and the Federal Reserve, 1863-1923. Ithaca, NY: Cornell University Press, 1977.

Wheelock, David C. "Member Bank Borrowing and the Fed's Contractionary Monetary Policy During the Great Depression." Journal of Money, Credit, and Banking, November 1990, 22, pp. 409-26.

The Strategy and Consistency of Federal Reserve Monetary Policy, 1924-1933. Cambridge: Cambridge University Press, 1991.

"Monetary Policy in the Great Depression: What the Fed Did and Why." Federal Reserve Bank of St. Louis Review, March/April 1992, 74(2), pp. 3-28.

White, Eugene N. The Regulation and Reform of the American Banking System, 1900-1929. Princeton: Princeton University Press, 1983.

Wicker, Elmus R. Federal Reserve Monetary Policy, 1917-1933. New York: Random House, 1966. 